DOI: 10.15393/j2.art.2016. 3321

Article

\title{
Natural resources and ecosystem services - a conceptual and contents account
}

\section{Olli Saastamoinen*}

School of Forest Sciences, University of Eastern Finland

* Author to whom correspondence should be addressed; E-Mail: olli.saastamoinen@uef.fi;

Abstract: Besides a tidal wave of research outputs, ecosystem services (ES) has brought also classifications, suggesting indirectly, that the material natural resource (NR) classifications have not caught all forms of human-nature interactions, important for human welfare. As there are traditions in NR literature to include also non-tangible NR, this paper assess differences, commonalities and types of novelty values ES concept has brought into wider understanding on NR. The contents of two advanced, but not new to have a time scale, NR classifications (by Owen 1971 and Reimers 1990) and the recent Common International Classification of ES (CICES) were compared. The definitional difference between NR and ES is that the latter are related to ecosystems only. The basic commonality is that provisioning ES, i.e. nutritional, material and energetic outputs correspond closely to the biotic NR. The novelty values of ES are usually thought to be regulating and cultural ES. Owen's NR has only a minor connection to ES but Reimers's NR includes many connections to the regulating ES categories of CICES. In cultural ES Owen has much and Reimers very much connections to CICES categories. While the connections of NR into ES categories are general and leave room for interpretations, it is concluded that Owen's classification of NR responds at least satisfactorily, and Reimers' NR classification rather well to the general contents of CICES (2013). ES have thus some history in the advanced NR classifications. Also the historical role of forest science and forestry in an early identification of services and processes now known as ES is briefly discussed as well perspectives to the development of wider integrated classifications. The epilogue include other views on future.

Keywords: Natural resource classifications, non-tangible natural resources, CICES, regulating and maintenance services, cultural services, integrated classifications, O.S. Owen, N.F. Reimers 


\section{Introduction}

The earliest definition of natural resources (NR) is the one related to Aristotle, who in his Politics [1] wrote: "Property, in the sense of a bare livelihood, seems to be given by nature herself to all". He did not use the NR term as such but it has been concluded that "natural means of livelihood" represents Aristotle's view on NR [2]. Aristotle also stated that "the art of getting wealth out of fruits and animals is always natural" and preferred this against making wealth through borrowing money. Two aspects of NR as use values for livelihood and their role as a property and wealth was recognized.

The multiple roles of NR as means of livelihood and as a source of wealth and power has through the history maintained the importance of and tensions around NR. Even in our times it has been stated that "natural resources or green capital are the drivers of globalization Despite the current age of technological innovation, it is natural capital which constitutes the physical basis for wealth" [2].

While NR have been in the core of natural sciences, economy and politics through the history, it is difficult to find when the very term 'natural resources' emerged into literature. For example, during the 18th century when economic sciences (political economy) departed from philosophy, Adam Smith [3] dealt widely with "the produce of land, mines and fisheries" but did not use the term of NR. "Land" in economics meant long time all natural factors of production.

As it has been said that the modern debate on natural resources and the sustainability of their management began in the late 18th /early 19th century [70], it is safe to assume that far more than a century, NR has been a dominating conceptual framework to describe and classify the useful things of nature and the natural wealth they compose. However, during past two decades this situation has somewhat changed. Competitive concepts have emerged.

While a variety of NR definitions exist, most of these have been and still are very much materially oriented. For example, NR are defined as "naturally occurring materials, including energy, useful for supporting life" [4], to "represent gifts of nature to our productive processes" [5] or seen to be "natural assets (raw materials) occurring in nature that can be used for economic production or consumption" [71].

In 1933 E. Zimmerman [6] introduced his functional interpretation of natural resources, which says that "a resource does not refer to a thing or substance but to a function which a thing or a substance may perform". In 1951 he emphasized that "Resources are not, they become; they are not static but expand and contract in response to human wants and human actions" [7].

This continues to be true for the material resources of nature. But in particular during the past decades after Zimmerman's thesis, the changing social objectives and values (recreation, tourism, environmental protection) have brought "non-tangible" resources of nature increasingly important and diversified $[8,9]$.

However, the "traditional" conceptualizations, definitions and classifications of NR have only weakly if not at all responded to these "new" resources of nature. For example, until 2000 economic geography was largely focused on [natural] resources as inputs for primary production [10], but "the nature that shows up in economic geography over the past ten years has seemed infinitely remote from the iron mines or timber stands of traditional resource economic geography" [11]. In part, the "new" questions are related to tenuous distinction between "resources" and "environment" to "ecosystem services" [11].

The dynamics of resource demands have also brought other concepts, such as "environmental resources" and "natural capital", which at general level better than "traditional" NR definitions are reflecting the changing interactions between society and nature. But during the past two decades the focus in this front has much been in ecosystem services (ES). 
There are several reasons why the research on ecosystem services has gathered increasing attention during the past two decades. These have been related to the changes in international biodiversity policies, which have strongly promoted ES concept $[12,13]$, to commodification of nature supported by neoliberal economic policies [11], increasing role of economic valuation in environmental policies and other - sometimes critically debated - aspects connected to ES [61]. Nevertheless, most of the fast growing research on ES is simply motivated by the scientific interests to identify, (re)discover and classify all the beneficial properties of biotic nature in order to facilitate their better consideration, valuation, management and conservation for the good of mankind and nature.

Unlike the other new concepts, including environmental resources, ecosystem services (ES) have from the very beginning become the objects of the systematic classifications. This development provides possibilities to compare ecosystem services and natural resources in more concrete terms than at the level of general definitions only.

\section{Purpose and study approach}

The main purpose of this paper is to compare the detailed contents of both natural resources and ecosystem services, in order to indicate what is their common contents and what are their fundamental differences. At the same the comparison demonstrates the extent and types of novelty values of ecosystems services in regard to natural resources. This may also give some perspectives to discuss the needs to develop further natural resource classifications or other alternatives for the integrated classifications of all the useful and valuable aspects of nature.

The structure of the paper provides some views on the definitions of natural resources (given above in Chapter 1) and presents two different classifications of natural resources (Chapter 3). At this stage it is already broadly indicated, which natural resource belongs to any of the major categories of ecosystem services, characterized in what follows.

The definitions of ES and the major ES categories are then presented and discussed (Chapter 4). Two ES classification schemes are shortly outlined but third on - the CICES - is presented widely, because it is used for the comparisons of ES with the natural resource classifications.

The detailed analysis of the common contents is done (Chapter 5) by indicating which natural resources of the two NR classifications have their "close" counterparts in the chosen ES classifications. Major common contents and differences are pointed. Some examples on borderline cases between ecosystem services and natural resources are also indicated and discussed.

Chapter 6 discusses the challenges and possibilities ES provides for the concept and classification of NR and also illustrates briefly, how within the specific natural resource field of forests many of the "new" ES have been recognized early and even included into forest management regimes. It also discusses how ES is related to the new concepts of environmental resources and natural capital and introduces some ongoing developments and efforts towards integration of NR and the "new" ES categories.

The first of the two last chapters gather main conclusions of this conceptual analysis (Chapter 7). An epilogue (Chapter 8) connects NR and ES to the decades long human efforts for sustainable management, protection and restoration of nature's wealth, and more recent discussion on the safe planetary boundaries. 


\section{Natural resources: two classifications}

According to the statistical office of the European Union 'Eurostat' [14] no commonly agreed definition of natural resources is available. Therefore, neither a universally accepted classification of NR exists. Instead of that, however there are many commonly accepted classification or grouping criteria such as divisions between renewable and non-renewable, exhaustible and non-exhaustibility as well as biotic or abiotic NR. Also, recyclability and major sources (e.g. biomes) or uses of resources (energy, raw materials) are usually recognized. These often form similar structures to the classification. However, the major distinction between existing NR classifications is the extent and the kinds of non-tangible resources included. As noted earlier, most classifications cover only material NR resources and their comparisons with ES classification can be analysed shortly as is found later. The major interest here is in the comparison of other than material NR with similar ES categories. Those NR classifications, which include also non-material NR are called here as "advanced" ones. This, of course, is a subjective and context related statement. When NR are defined as material ones, their classification can be very detailed, logical and advanced.

Not so many alternatives were found for that purpose, but the two classifications chosen meet the above criteria. The first is that of O.S. Owen [15, Table 1] and represents multi-criteria classification of natural resources based on the scope of conservation ecology. The choice of the classification dating back over 40 years gives some perspective for the development in the classification.

The second classification of natural resources compiled by N.F. Reimers in 1990 [16, Table 2] can be called as a generic classification of NR because it is mainly based on the sources and places of the resource in the larger systematic structure of nature. Neither this younger reference is very new but nevertheless used relatively recently both in a textbook [17] and cited in scientific literature [18].

Table 1. A multi-criteria classification of natural resources (Owen 1971, 15) with tentative notions whether a resource is also an ecosystem service. PES $=$ Provisioning, RES $=$ Regulation and maintenance, $\mathrm{CES}=$ Cultural and SES = Supporting ES.

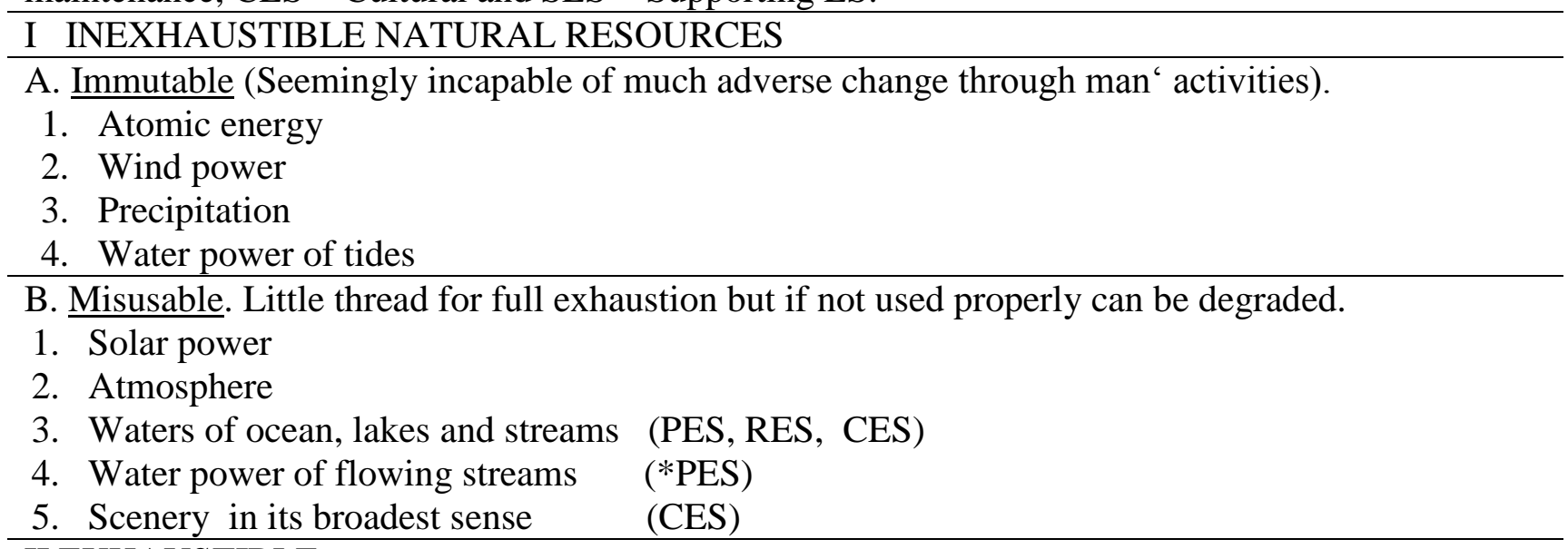

\section{EXHAUSTIBLE}

A. Maintainable. Those resources, in which permanency is dependent upon method of use by man.

1. Renewable. The living (biotic) or dynamic resources, whose perpetual harvest is dependent upon proper management and planning.
a. Local water
(PES)
b. Soil fertility
(RES)
c. Products of the land 
Table 1 (continued).

(1) Agricultural products (Vegetables, grains, fruits, fibers, etc) (PES)

(2) Forests (Source of timber and wood pulp) (PES)

(3) Forage land

(PES)

(4) Wild animals

(PES)

d. Products of lakes, streams and impoundments (PES)

e. Products of the ocean

(PES)

f. Human powers

2. Nonrenewable. Once lost, there is no hope to be reversed.

a. Species of wildlife ("end products of.. a million years of evolution") (CES)

b. Specimen wilderness ("within .. human lifespans .. cannot be restored") (CES)

B Non-maintainable. Mineral resources. Total quantity is static. Are regarded as wasting assets. When destroyed or consumptively used, they can not be replaced.

1. Reusable. Minerals, the consumption of which is tiny. Harvesting or recycling potential is great.

a. Gem minerals

b. Nonconsumptively used metals. Gold, platinum, and silver; some iron, copper, and aluminium

2. Nonreusable.

a. Fossil fuels

b. Most nonmetallic minerals

c. Consumptively used metals

Table 2. Generic classification of natural resources by N.F. Reimers $(1990,16)$ with tentative notions whether a resource can be regarded as an ecosystem service. PES $=$ Provisioning, RES = Regulation and maintenance, $\mathrm{CES}=$ Cultural ecosystem service.

\section{Energetic resources}

A Participating permanent/continuous cycle and energy notoke
1.1 Solar energy (Solar radiation and all energetic processes it

in facilitates: energy of wind, wave, sea torrents, air temperature, cycle temperature difference between surface and bottom layers of waters etc ) and lower levels

1.2 Cosmic energy

1.3. Tidal energy

1.4. Geothermal energy

1.5. Gravitation energy and energy of pressure

1.6 Electricity of atmosphere

1.7 Earth magnetism

1.8 Energy of spontaneous chemical reactions and natural atomic paspada

1.9 Bioenergy (" all forms from burning firewood to sprit and biogas') [PES]

1.10 Secondary forms of energy ('waste heat, etc)

B. Deposit

energetic

1.11. Oil

resources

1.13 Coal

1.14 Shale oil

1.15 Peat (*PES) 
Table 2 (continued).

\begin{tabular}{|c|c|}
\hline C. Artifcially activated & 1.16 Nuclear energy \\
\hline energy sources & 1.17 Thermonuclear energy \\
\hline 2 Atmospheric gas resources & \\
\hline & 2.18 Specific resources of atmospheric gases ( ozone, $\mathrm{O}_{2}, \mathrm{CO}_{2}$ ) \\
\hline & 2.19 Gas substances /formations of hydrosphere \\
\hline & 2.20 Gas substances/formations of soils \\
\hline & 2.21 Ozone screens \\
\hline & $\begin{array}{l}2.22 \text { Phytocides and other biogenic floating substances (little used } \\
\text { resources by people, forming important conditions for maintenance } \\
\text { of human health [PES] }\end{array}$ \\
\hline & 2.23 Ion contents of atmosphere \\
\hline & 2.24 Pollutant gases (“Antiresource") \\
\hline
\end{tabular}

\section{Water resources}

4 Lithosphere resources

3.25 Atmospheric moist

3.26 Ocean waters (RES )

3.27 Continental waters (PES, RES)

3.28 Water flows * vodotiki

3.29 Temporal small waters 3

.30 Moisture, related to vegetation and wildlife [in particular arid areas]

3.31 Liquid surface pollutants [ "Antiresources"]

3.32 Hydrogeological resources (PES)

3.33 Soil moisture

3.34 Deep liquid pollutants [Resources and "Antiresources"]

\begin{tabular}{|c|c|}
\hline \multirow[t]{5}{*}{ A. Soil and land resources } & 4.35 Soil (RES) \\
\hline & 4.36 Sub-soil and mineral types \\
\hline & 4.37 Cryogenic substrates (ice, permafrost and mountain ice) \\
\hline & 4.38 Soil pollution [“Antiresource"] \\
\hline & 4.39 Soil erosion ["Antiresource"] \\
\hline \multirow[t]{3}{*}{ B. Geomorphological } & 4.40 Geomorphological structural resources \\
\hline & 4.41 Geomorphological spatial resources \\
\hline & $\begin{array}{l}\text { 4.42 Geomorphological deep resources [geological process, mostly } \\
\text { "antiresources"] }\end{array}$ \\
\hline \multirow{3}{*}{$\begin{array}{l}\text { C. Non-energetic mineral } \\
\text { resources }\end{array}$} & 4.43 Metallic ores \\
\hline & 4.44 Non-metallic ores \\
\hline & 4.45 Non-ore minerals, including leading minerals \\
\hline
\end{tabular}

5. Resources of producer plants

5.46 Genetic- species composition of plants [Plant species, protection of which maintain the appearance of the planet's ecosystems (PES)

5.47 Plant biomass (PES)

5.48 Primary production

5.49 Economically valuable plant production (PES)

5.50 System-dynamic qualities of the photosynthesis 
Table 2 (continued).

5.51 Cleaning capacity of plants (RES)

5.52 Botanical "pollutants" ["Anti-resources"]

6. Consumer resources

6.53 Genetic-species composition of consumers [Species of animals and plant-produces, playing regulatory role in the ecosystems, (RES)]

6.54 Consumer biomass (PES)

6.55 Secondary biological production (PES)

6.56 Economic production of consumers (PES)

6.57 System-dynamic qualities of consumers

6.58 Role of consumers (in particular animals) as sanitary, pollination of plants, chemical substances, etc (RES)

7. Resources of reducents

6.59 Consumer "pollutants" [Anti-resource"]

7.60 Genetic-species composition of reducents (RES)

7.61 Reducent biomass (PES)

7.62 Physical-chemical activity of reducents (RES)

7.63 System-dynamic qualities of reducents

7.64 Microbiological (including virus-related) pollutants [“Antiresource]

\section{Climatic resources}

8.65 Natural climatic resources

8.66 Modified climatic resources (of local climate) [including nonpurposeful. e.g. in cities) and agro-forestry improvements (RES)

\section{Recreational-anthropologic-ecological resources}

9.67 Resources of natural environment for optimal everyday living conditions for humanity (CES)

\begin{tabular}{l}
\hline 9.68 Recreational resources (CES) \\
\hline $\begin{array}{l}9.69 \text { Curative natural resources (natural agents, having health } \\
\text { promoting properties) }\end{array}$ \\
$\begin{array}{l}9.70 \text { Nature-based hearth illnesses and transmissible diseases } \\
\text { ["Anti-resources"] }\end{array}$
\end{tabular}

\section{Cognitive-informational resources.}

10.71 Nature- primeval resources (CES)

10.72 Natural historical cognitive -informational resources (CES).

\section{Space and time resources}

11.73 Space resources (territorial, aquatic, air, including close cosmos, space).

11.74 Time resources [This includes a comment: Sharpening ecological problems are giving less and less time for their solutions].

Although ecosystem services are in more detailed way introduced in the next Chapter 4, in both classifications (Tables 1 and 2) one can already find notions, if a specific resource is regarded as being also an ES according to any of the following four major categories: Provisioning ecosystem services (PES), Regulation and maintenance ecosystem services (RES) and Cultural ecosystem 
services (CES). The notion (*ES) refers to an ES, the inclusion of which is debated in the literature. Some of these are considered in Chapter 5. The definitions of major categories are also found in the following Chapter 4, which also includes the hierarchic structure of the Common International Classifiction of Ecosystem Services (CICES Version 4.3) [19]. Supporting ecosystem services (SES) are not included.

While the CICES recognizes the fundamental importance of supporting services (SES), it does not include these life-supporting ("intermediate") services into the classification as a separate $\left(4^{\text {th }}\right)$ major category, because these participate in the formation of all other three categories of ecosystem services, regarded as final ecosystem services. By exclusion of supporting ES one avoids double counting, for example in valuation of ES. However, the borderlines between supporting (SES) and regulation and maintenance services (RES) is sometimes context dependent (20).

The classification of Reimers (1990, Table 2) [16] contains 11 major resource categories, divided sometimes into A $-\mathrm{C}$ groups and altogether 72 classification units (resources). The identified resources (classification units) run from 1.1. to 11.72. Almost all resource titles have given clarifying comments, explaining their roles, functions, and other aspects. Only some of them are included into Table 2.

The comments also classify several resources as "antiresources". Many of these correspond to things sometimes called as "disservices" in ecosystem service literature, for example poisonous mushrooms and snakes. They are not a part of any major classification scheme, but were listed separately in the classification of ecosystem services of boreal forests in Finland [20].

\section{Ecosystem services and their classifications}

The term 'ecosystem services' has occasionally used already from the late 1960s [12], but the concept got more scientific attention from the latter half of 1990s [21, 22 ]. According to an early definition [21] "Ecosystem services are the conditions and processes through which natural ecosystems, and the species that make them up, sustain and fulfill human life". While this definition is ecologically oriented, the further text makes it clear that all major categories of E (provisioning, regulation, cultural and support services) are included.

In 2005 Millenium Ecosystem Assessment (MEA) [12] brought the ES concept visible as a key communication vehicle to demonstrate the threats of biodiversity loss and the destruction and degradation of world's major ecosystems. The message was that alongside ecosystems, also their vital services for mankind, among which many important services were even hardly recognized, will also be lost. The four major categories of ES were illustrated by MEA as follows [12]:

1. Provisioning services or material goods such as food, firewood, potable water, game;

2. Regulation and maintenance services such as binding carbon from the atmosphere, pollination or removing toxic substances from the soil;

3. Cultural services such as recreation environments, landscapes, and symbolic trees or charismatic animals.; and

4. Supporting services being life supporting processes, such as photosynthesis, water cycle, energy flow and nutrition cycle. These are fundamental ecosystem processes, facilitating and being often intermediate processes of the ecological production of the three first categories.

Mainly for the communication purposes MEA [12] developed a popular and concise definition: "Ecosystem services are the benefits people obtain from ecosystems". However, the scientific literature does not define ecosystem services as benefits, but as the UK National Ecosystem Assessment (UK NEA) [23] formulates ES "are the outputs of ecosystems from which people derive benefits". 
Since the emergence of the ES concept, several classification systems have been developed. Three classifications have a broader international status, besides MEA [12] also The Economics of Ecosystems and Biodiversity (TEEB) [13] and the Common International Classification of Ecosystem Services (CICES ) [19] used here.

The TEEB [13] can be seen as an economic extension of MEA [12]. Its background report [13 Kumar 2010] contains comprehensive ecological, economic, social and even moral foundations for ecosystem services and their valuation. TEEB is also a process, in which national and regional ecosystem services assessments are carried out using its classification structure and other approaches. Several TEEB-based national assessments have been done (www.teebweb.org/), including a wide Nordic survey [24] and an extensive TEEB - Finland [25]. The purposes have not been in systematic classifications as such but in broader socio-economically oriented assessments of ecosystem services.

The CICES [19] arose from the work of the European Environment Agency (EEA) to develop land and ecosystem accounts [19]. It represents the most systematic effort to develop further the classification of ecosystem goods and services found in MEA [12], TEEB (2010) and other earlier classifications [see e.g. 27, 35]. However, it needs to be recognized the foundational roles of the international contributions of thousands scientists and experts involved in the preparation of MEA 2005 [12]. Also the scientific foundations and policy documents of TEEB 2010 [13] are results of wide scientific cooperation.

Being framed around human needs like the other major ES classifications, CICES primarily describes ecosystem outputs as they directly contribute to human well-being. A fundamental characteristic of final ecosystem services is that they retain a connection to the underlying ecosystem functions, processes and structures that generate them. Ecosystem goods and benefits obtained from final services by using human inputs can also be referred to collectively as 'products' [19].

In the implementation context of the EU Biodiversity Strategy 2020, it has been suggested to use CICES for classification purposes [26]. The CICES has thus gained a status for classification of ES within the EU. It is designed to allow for multipurpose applications and to serve ES mapping, assessment, valuation as well as social, aesthetic, and physical accounting [27].

The most important feature of CICES is its hierarchial structure, which in the latest CICES version 4.3. developed to contain five-levels (section, division, group, class, class type) [19].

The structure and contents of CICES at 4-digit level is presented in Table 3. The whole classification with five levels and examples is available in the form of Excel-table (www. cices.eu).

CICES has the following definition for ecosystem services at the section levels [19]:

a. Provisioning services: all nutritional, material and energetic outputs from living systems. In the proposed structure a distinction is made between provisioning outputs arising from biological materials (biomass) and water.

b. Regulating and maintenance services: covers all the ways in which living organisms can mediate or moderate the ambient environment that affects human performance. It therefore covers the degradation of wastes and toxic substances by exploiting living processes. It also covers the mediation of flows in solids, liquids and gases that affect people's performance as well as the ways living organisms can regulate the physico-chemical and biological environment of people.

c. Cultural services covers all the non-material, and normally non-consumptive, outputs of ecosystems that affect physical and mental states of people [19].

The area of cultural services was seen to be problematic as terminologies used by the wider community do not make a distinction between services and benefits; the term recreation was, for example, particularly problematic in this respect. It was noted that provisioning or regulating services also can have a cultural meaning [19]. 
Table 3. CICES V4.3 - classification of the ecosystem services at four levels (the most detailed subclass level left out. The practical applications usually enter at class and sub-class levels [19]. Numbering of classes is only to facilitate comparisons with natural resources (Tables1 and 2).

\begin{tabular}{|c|c|c|c|}
\hline $\begin{array}{l}\text { SECTIO } \\
\mathbf{N}\end{array}$ & DIVISION & GROUP & $\begin{array}{l}\text { CLASS [Note: Numbering is not used in CICES, but added here } \\
\text { for the better communication within the text.] }\end{array}$ \\
\hline \multirow{6}{*}{$\begin{array}{l}\text { Pro } \\
\text { visio- } \\
\text { ning }\end{array}$} & \multirow[t]{2}{*}{ Nutrition } & Biomass & $\begin{array}{l}1 \text { Cultivated plants } 2 \text { Domestic animals \&outputs } 3 \text { Wild plants \& } \\
\text { mushrooms } 4 \text { Wild animals \& outputs } 5 \text { Plants, algae in situ aquaculture } \\
6 \text { Animals from in situ aquaculture }\end{array}$ \\
\hline & & Water & 7 Surface water -drinking 8 Ground water -drinking \\
\hline & \multirow[t]{2}{*}{ Materials } & Biomass, Fibres & $\begin{array}{l}9 \text { Fibres and materials from plants and animals for direct use and } \\
\text { processing. } 10 \text { Materials from plants, algae and animals for agricultural } \\
\text { use } 11 \text { Genetic materials from all biota }\end{array}$ \\
\hline & & Water & 12 Surface water non-drinking 13 Ground water non-drinking \\
\hline & \multirow[t]{2}{*}{ Energy } & $\begin{array}{l}\text { Biomass-based energy } \\
\text { sources }\end{array}$ & 14 Plant-based resources 15 Animal based resources \\
\hline & & Mechanical energy & 16 Animal based energy \\
\hline \multirow{10}{*}{$\begin{array}{l}\text { Regula- } \\
\text { tion \& } \\
\text { mainte- } \\
\text { nance }\end{array}$} & \multirow{2}{*}{$\begin{array}{l}\text { Mediation of } \\
\text { waste, toxics } \\
\text { and other } \\
\text { nuisances }\end{array}$} & Mediation by biota & $\begin{array}{l}17 \text { Bio-remediation by micro-organisms, algae, plants } \\
18 \text { Filtration, sequestration, storage, accumulation by biota }\end{array}$ \\
\hline & & $\begin{array}{l}\text { Mediation } \\
\text { ecosystems }\end{array}$ & $\begin{array}{l}19 \text { Filtration/sequestration /storage /accumulation of harmful materials by } \\
\text { ecosystems } 20 \text { Dilution by atmosphere, freshwater and marine eco-systems } \\
21 \text { Mediation of smell/ noise/visual impacts }\end{array}$ \\
\hline & \multirow[t]{3}{*}{$\begin{array}{l}\text { Mediation of } \\
\text { flows }\end{array}$} & Mass flows & $\begin{array}{l}22 \text { Mass stabilization and control of erosion } 23 \text { Buffering and attenuation of } \\
\text { mass flows }\end{array}$ \\
\hline & & Liquid flows & 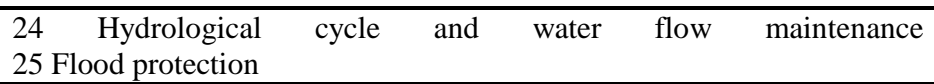 \\
\hline & & Gaseous / air flows & 26 Storm protection 27 Ventilation and transpiration \\
\hline & \multirow{5}{*}{$\begin{array}{l}\text { Maintenance } \\
\text { of physical, } \\
\text { chemical and } \\
\text { biological } \\
\text { conditions }\end{array}$} & $\begin{array}{l}\text { Lifecycle maintenance, } \\
\text { habitat and gene pool } \\
\text { protection }\end{array}$ & 29 Maintaining nursery populations and habitats \\
\hline & & $\begin{array}{l}\text { Pest and disease } \\
\text { control }\end{array}$ & 30 Pest control 31 Disease control \\
\hline & & $\begin{array}{l}\text { Soil formation and } \\
\text { composition }\end{array}$ & $\begin{array}{l}32 \text { Weathering processes } \\
33 \text { Decomposition and fixing processes }\end{array}$ \\
\hline & & Water conditions & $\begin{array}{l}34 \text { Chemical conditions of freshwater } 35 \text { Chemical conditions of salt } \\
\text { waters }\end{array}$ \\
\hline & & $\begin{array}{l}\text { Atmospheric } \\
\text { composition and } \\
\text { climate regulation }\end{array}$ & $\begin{array}{l}36 \text { Global climate regulation by reduction of greenhouse gas } \\
\text { concentrations } 37 \text { Micro and regional climate regulation }\end{array}$ \\
\hline \multirow[t]{4}{*}{$\begin{array}{l}\text { Cultura } \\
1 \\
\text { services }\end{array}$} & $\begin{array}{l}\text { Physical } \\
\text { and } \\
\text { intellectual } \\
\text { interactions } \\
\text { with ecosys- }\end{array}$ & $\begin{array}{l}\text { Physical and expe- } \\
\text { riential interactions }\end{array}$ & $\begin{array}{l}38 \text { Physical recreational use of ecosystems and environments } \\
39 \text { Experiential use of plants, animals, ecosystems and } \\
\text { environments in-situ }\end{array}$ \\
\hline & $\begin{array}{l}\text { with ecosys- } \\
\text { tems and } \\
\text { land/sea- } \\
\text { capes }\end{array}$ & $\begin{array}{l}\quad \text { Intellectual and } \\
\text { representational } \\
\text { interactions }\end{array}$ & $\begin{array}{l}40 \quad \text { Scientific } \quad 41 \\
43 \text { Entertainment } 44 \text { Aesthetic }\end{array}$ \\
\hline & $\begin{array}{l}\text { Spiritual, } \\
\text { symbolic \& }\end{array}$ & $\begin{array}{l}\text { Spiritual } \\
\text { emblematic }\end{array}$ & 45 Symbolic 46 Sacred and/or religious \\
\hline & $\begin{array}{l}\text { other inter- } \\
\text { actions with } \\
\text { ecosystems } \\
\text { and land/sea- } \\
\text { scapes }\end{array}$ & $\begin{array}{l}\text { Other } \\
\text { outputs }\end{array}$ & 47 Existence 48 Bequest \\
\hline
\end{tabular}


So far the empirical applications are not so many. In Belgium for the local conditions modified version called CICES-Be, where some changes were done also at group and class-levels [28]. It is an important national-level contribution. An earlier version of that work was used as an input in CICES V4.3 development. In Finland, the classification of freshwater ES combined several classification schemes, including an earlier CICES V3 version [29]. CICES V3 was also used in the classification of agricultural ecosystem services [48]. Forest ecosystem service classification in Finland (13) followed strictly the CICES V4.3 categories but found an additional $6^{\text {th }}$ hierarchy level as useful. A more general classification combining forest, peatland, freshwater and aquatic ES has been drafted into a report on ES in Finland [30].

\section{Natural resources and ecosystem services: common contents and borderline cases}

Compared to ecosystem services, natural resources cover much wider area of the nature's elements. ES are related only to biotic nature: species, ecosystems and biomes with their abiotic environment. On the other hand, in regard to the human welfare, ES has a broader scope than that those of mainstream NR classifications, including useful ecosystem processes (regulation and maintenance services) and non-consumptive interactions with nature (cultural ecosystems services). Both are in many ways related to human welfare, but - as stated earlier - have largely been neglected in the definitions and classifications of natural resource. Exceptions such as analysed here (Tables 1 and 2) are not common. Therefore, these two larger categories make the major differences between the conventional NR concept and ES concept.

In the following, the commonalities found between NR and ES are (tentatively) identified in the text and Tables 1, 2 and 3. The comparisons are first done between the Provisioning ES classes (116) of CICES (Table 3) and NR in Owen's classification (Table 1) and then with NR in Reimers' classification (Table 2). Secondly, similar comparisons are done between Regulation and maintenance ES classes (17-37) of CICES (Table 3) and NR of Owen (Table 1) and NR of Reimers (Table 2). Finally, the comparisons are carried out between Cultural ES classes (38-47) of CICES (Table 3) and NR of Owen (Table 1) and Reimers (Table 2). In the same context, also some borderline ES cases are discussed.

The basic commonality is that all Provisioning ecosystem services (Table 3): Nutrition (CICES 1-8), Materials (CICES 9-13) and Energy (CICES 14-16), mostly related to material products, are renewable biotic natural resources. This is generally true also vice versa.

In Owen's classification (Table 1) they are primarily found in II .A.1. (Exhaustible. Maintainable. Renewable): a. Local water, b. Soil fertility (also RES) c. Terrestrial crops (Agricultural, Forests, Range, Wildlife), d. Crops of lakes, rivers and ponds, e. Ocean products.

In Reimers' classification (Table 2) provisioning services are found in several main categories (given in italics): 1. Energetic resources, where is A.1.9 Bioenergy; 3.Water resources (subcategories $3.26-3.29,3.33$ ); 5. Resources of primary producers (5.47 Plant biomass); 6. Resources of consumers (6.54-6.56 Consumer biomass etc.); and in 7. Resources of decomposers (7.61 Decomposer biomass).

Common contents of provisioning services include also the genetic materials of all biota (CICES 11). Reimers has listed these separately for three types of biota [46, 53, 60]. Owen does not include genetic materials explicitly.

As an energetic natural resource Owen has both tidal (I.A.4) and stream (I.B.4) water power. Similarly Reimers has tidal (1.A.1.3) and stream energy as a part of gravitational energy (1.A.1.5). In addition, the category 5. Water resources of Reimers include a comprehensive list of the forms of water existing in ecosystems. 
Among these energetic resources there are two natural resources which can be seen as the "borderline" cases as ecosystems services: energy peat and water power.

Peat as an energy resource is in Reimers's system included into 1.B. Deposit energy resource (1.15) among oil, natural gas and coal. Also the EU energy policy has classified peat into nonrenewable resources. The peatland strategy of Finland [31] saw energy peat as a provisioning service, but it is much debated as an ES because its extraction causes drastic ecosystem impacts such as destruction of natural peatland ecosystem, carbon releases, water loads, biodiversity and landscape losses [32]. The TEEB for Finland [25] included energy peat as ES as also did UK NEA [62]. However, there has also been a position in the UK that the extraction of even growth and environmental peat is not a provisioning service due to the adverse environmental impacts. CICES does not recognize it as a provisioning service but neither is it so far present in its (provisional) accompanying classification of abiotic outputs from natural systems [19]. On the other hand, peat in situ is regarded as a regulation service, because it binds carbon [33] and therefore peatland restoration should be promoted [34]. In short, views on energy peat as ES have been mixed [35].

Haynes-Young \& Potchin (2013) reports that during the development process of the CICES, water was regarded by some primarily as an abiotic, mineral output. The majority argued, however, that it should be included; due to its already wider usage as an ecosystem service and because water bodies of all scales host communities of species that provide ecosystem services themselves. Similarly, in Finland, the land of thousands of lakes and other aquatic ecosystems, the idea to exclude water from ecosystem services sounded as strange [35]. Water for nutrition and many other uses is an ES.

However, the hydropower is a borderline case, as it was earlier included in CICES Classification as a part of Provisioning services among other "Renewable abiotic energy" (wind, solar, tidal and thermal), but the later consensus was to "exclude non-ecosystem based natural flows, i.e., renewable abiotic energy sources and abiotic materials" [19]. These forms of energy are now a part of the (provisional) accompanying classification of natural resources of the CICES [19]. Again, the most common view is that hydropower is not an ES. The hydropower and peat are theoretically interesting borderline cases, in particular concerning the criteria used. But this can not be discussed further here.

All biotic natural resources are ecosystem services, and most of them are relatively easily recognized as provisioning services. It means that neither at the conceptual level nor in regard to the identification of provisioning services, the concept of ecosystem services has not brought any essential novelties compared to the knowledge already existing in the sphere of natural resources. The fact that the coverage of material resources of nature is much wider in NR classifications than that of ES is of course evident also in Tables 1 and 2.

However, the opposite is true in regard to the second major category of the ES: regulation and maintenance services. In the general natural resource literature these processes have traditionally been given little if any attention.

This is true also in Owen's classification (Table 1), which does not directly identify resources in their capacity to influence and improve human environment. Only the definition of soil fertility, as the ability of soil to produce plant substance desirable to man (Owen II. A. 1 b), can be seen to be close to Soil formation and composition, a regulation service (CICES classes 32, 33). Soil formation can also seen as an intermediate / supporting ES.

Reimers's (1990) generic classification (Table 2) has a wide holistic view and it primarily covers systematically the main resources provided by the atmosphere, lithosphere, hydrosphere and biosphere. Biosphere is divided into three categories. 
Among main Category 2. Atmospheric gas resources, there is 2.22 Phytocides and other biogenic floating particles, which were seen to forming important conditions for the maintenance of human health. It can be classified as a part of Micro and regional climate regulation (CICES class 37).

Many elements of main Category 3. Water resources have regulation and maintenance roles, such as 3.25 Atmospheric moist, 3.26 Ocean waters, 3.27 Continental waters, 3.28 Smaller scale waters, and 3.29 Temporal small waters, and therefore are parts of CICES 24 Hydrological cycle and water flow maintenance. Even 3.30 Moisture, related to vegetation and wildlife [in particular arid areas] has a small but sometimes a vital regulation and maintenance role.

Also in Category 4. Lithosphere resources 4.35 Soil describes the process of natural soil formation including besides organisms also the necessary abiotic factors. It corresponds to CICES categories 32 and 33. Reimers has both 4.38 Soil pollution and 4.39 Soil erosion as "Antiresources". With an (now lacking) identification of vegetation, plants or other organisms, which could mitigate pollution or control erosion, these could be easily translated into ES. Actually, Category 5. Resources of primary producers includes 5.51 Cleaning capacity of plants, corresponds to CICES 17 Bio-remediation by micro-organisms, algae, plants and animals.

Also in Category 6. Consumer resources, 6.58 Role of consumers (in particular animals) as sanitary, pollination of plants, chemical substances, etc. belongs to CICES 17 while pollination goes to CICES 28 Pollination and seed dispersal.

Among Category 7. Resources of decomposers, 7.62 Physical-chemical activity of decomposers, play regulation and maintenance roles in CICES 32 Weathering processes and in CICES 33 Decomposition and fixing processes. Also 7.63 System-dynamic qualities of decomposers can be related to above.

In Category 8. Climatic resources there are 8.65 Natural climatic resources, which - although not given in detail - apparently include forests, peatlands and oceans which maintain and/or bind carbon - and are thus important parts of CICES 36 Global climate regulation by reducing greenhouse gas concentrations. The other category 8.66 Artificially changed climatic resources (of local climate) include agro-forestry improvements and belong to CICES 37 Micro and regional climate regulation

It was stated earlier that cultural ES bring also many new aspects in regard to the views and values of nature if compared to the conventional classification of NR. However, less so in regard to the two advanced classifications examined here.

Owen (1971, Table1) has three resource categories, which are cultural ES. The first is I.B.5. Scenery in its broadest sense. It is described as aesthetic values subject to impairment of human activities. Examples consists of the most famous natural sights in the USA, such as Grand Canyon. This directly refers to CICES 44 Aesthetic [interactions] but are close also to CICES 42 Heritage, cultural.

The other two are Species of wildlife (II.A.2.a.) and Specimen wilderness (II.A.2.b.), of which the first primarily belongs to CICES 47 Existence values and the latter to CICES 48 Bequest values. Both are non-renewable NR, the former becomes extinct if lost and the latter cannot be restored within several human life-spans (Table 1). It can be added that to maintain nursery populations and habitat in the landscape is related to regulation and maintenance service (CICES class 29), although not explicitly given by Owen (Table 1).

The above Owen's categories may be among the earliest examples of recreational and other cultural resources found in general natural resource classification. Of course, in other NR literature these have been discussed much earlier (e.g. 39).

Among the eleven major categories of Reimers (Table 2) the three last ones belong to the scope of cultural ES. 
Category 9. Recreational-anthropological-ecological resources includes 9.67 Resources of natural environment for optimal everyday living conditions for humanity. "Everyday living conditions" makes this a bit broader than CICES 38 Physical recreational use of ecosystems and environments, which fits best to Reimers's 9.68 Recreational resources although this is not spatially defined. CICES 39 Experiential use of plants, animals, ecosystems and environments in-situ is neither site-bound and examples given in CICES include activities from bird watching to such an exotic experience as whale watching. Reimers's 9.69 Curative natural resources (natural agents, having health promoting properties) has not a direct counterpart in CICES. Neither Reimer's 9.70 Nature-based local illnesses and transmissible diseases ["Antiresource"] has a counterpart in CICES but it can be added that "disservices" of forests have been given a separate chapter in the Finnish forest ES classification [20].

Category 10. Cognitive-informational resources are broadly defined as objects and phenomena of nature allowing people to understand recent and past states of the planet and even grasp future. It consists of 10.71 Nature- primeval resources and 10.72 Natural historical cognitive -informational resources, which have their more specific counterparts in CICES classes 40 Scientific, 41 Educational and 42 Heritage, cultural ES.

Reimers's last Category 11. Space and time resources, includes 1.73 Space resources (territorial, aquatic, air, including close cosmos, space), which has not direct counterpart in CICES, except that conceptually it includes all terrestrial and aquatic ecosystems. The last one, 11.74 Resources of time (which includes a comment: Sharpening ecological problems are giving less and less time for their solutions) is commented in the last chapter.

The ways and criteria of connecting or translating natural resources into ecosystems services in this tentative attempt no doubt leaves some room also for other interpretations. Nevertheless one can conclude that Reimers' (1990) classification of NR responds rather well to the contents of CICES classification.

\section{Discussion: paths towards integrated classifications}

The social and economic dynamics, emphasized by E. Zimmerman already from 1933 [6, 7], concern not only new substances of the material natural wealth, but similarly also nature's "nontangible" (aesthetic, recreational) and protective (local climate, erosion prevention) resources and properties. The concepts and classifications of ecosystem services have brought these nature's beneficial features and processes systematically visible.

The general and most common materially oriented NR definitions and categories have largely dismissed this kind of resource and value dynamics.

This is interesting, because in particular within the sphere of the major terrestrial natural resouces - forests - the protective functions of forests have been recognized by early forest science from the $18^{\text {th }}$ century $[37,38]$. Similarly, the recreational and aesthetic resources of forests have also been given early attention before and in particular after the World War II, and been under increasing focus in research and practice [39]. Theoretical and practical approaches developed to conceptualize and manage the multiplicity of the goods and services of forests include the theory of forest functions [65], multiple use of forests [8], multifunctional forestry [66], integrated forest management and more recently as forest ecosystem management [47 Nask]. Most widely these approaches have been developed and adopted in public forests. The functions and resources have also been confirmed and supported by forest legislation in many countries [40, 41, 42]. It would earn a separate to study why forestry experiences and practises have that little reflected in the contents of general natural resource definitions and classifications. However, it seems that forest practises and science have had impacts on the two advanced NR classifications considered here 
$[15,16]$ both originating from large forest rich countries. The same holds true also in the smaller scale elsewhere. It can even be, that many NR classifications are only done for national purposes and reflect therefore better the variety of domestic resources and needs.

In our times, however, integrated classifications and approaches are needed more than ever for the proper assessment, management and conservation of all tangible and non-tangible natural resources and ecosystem services. This is not a novel observation as some development in this front as already been going on. The following discussion features briefly some of the efforts in this front.

Besides forest sciences, the importance of the non-tangible resources of nature to human welfare have, occasionally at least, been recognized in conservation ecology [15], geography [16, 43, 44], environmental science [45], in ecological and environmental economics [46, 47] and most recently - but also most systematically, in ES science [21, 22, 49], just to name some wellknown. Except in ES science, this development has mostly occurred at the conceptual level, as also some of the following demonstrate.

A concept 'environmental resources' (ER) was used by the World Commission on Environment and Development (WCED) [50] more often than NR but without explicit definition. It became the title of textbook in 1995 [44], where it was defined as the new 'general' category, containing three sub-categories: 1) NR understood as material resources 2) cultural ES without using ES term, and 3) "essential life-support system for humans" including regulation services but also food and drinking water [44]. While the major contents was about traditional NR, with some extensions on two other sub-categories, it in principle merits of adopting a broader scope to the resources of nature - although practically not using NR term. The change of the "name" or "game" was argumented using Zimmerman's functional NR theory [44]. It can be mentioned that in the same year 1995 a FAO report also recognized ER but kept NR as main category [51].

More recently, in environmental economics [46] 'the environment' was understood to "mean all natural resources in the biosphere, including land, land cover, and ecosystems (flora and fauna), resource deposits under the land surface; the world's oceans and atmosphere; and the natural climate and nutrient cycles". It was added that the resources of environment also include ES.

As no common definition of NR exists, EU's Eurostat [14, cf. 54] developed its own working definition, which includes a (provisional) structure of the following elements: 1. Raw materials 2. Energy resources 3. Air 4. Water 5. Soil 6. Spatial resources 7. Biodiversity and 8. Other ecosystem resources [14]. While Eurostat emphasized that it did not try to prescribe any particular classification of NR, the inclusion of ES into NR gives an important message that non-tangible processes and services of nature are regarded as part of NR.

The System of National Account (SNA) has for decades provided the cornerstone framework and statistics about the development of the national economies in the terms of Gross Domestic Product (GDP). SNA includes the contributions of material NR and provisioning ES, as far as they are related to market activities or household uses. A complementary System of Environmental and Economic Accounting (SEEA) [52] has also been under development. It adopted a concept 'environmental assets' to indicate 7 groups of stocks of common natural resource groups [52]. In addition, SEEA Experimental Ecosystem Accounting (EEA) [53] was developed aiming at a coherent and integrated approach to the assessment of the environment through the measurement of the stocks of ecosystems (ecosystem assets) and the flows of services (ES) from ecosystems into economic and other human activity. Although the work is experimental, it makes a synthesis of the knowledge in this area, and provides a common set of terms, concepts, accounting principles, classifications (based on an earlier version of CICES) and an integrated accounting structure of ES and ecosystem condition in both physical and monetary terms [53].

One can assume that the general frameworks above will facilitate an important avenue for the coherent development of the integrated classification of natural /environmental resources and 
ecosystem services, although so far the components are in different parts of SNA - SEEA - EEA structures. It needs to be noted that ES as defined in SEEA-EEA exclude [of course] abiotic services and hence do not encompass the complete set of flows from the environment. A complete was suggested to be reflected in the term "environmental goods and services" [53].

\section{Conclusions}

Natural resources (NR) has long been the dominant concept in research, practice and policy to analyse and manage the interactions between society and nature.

Most definitions and classifications of natural resources (NR) are materially oriented and have reflect poorly non-tangible resources of nature, the importance of which has continuously grown in particular since the 1950s. This is among the reasons why some new concepts have emerged, which try to conceptualize and make visible the lesser-known or weakly recognized characteristics of nature. Ecosystem services (ES) is most important among the new concepts, because it covers a well-specified area and has led to the development of systematic classifications in its field. In particular, this concerns regulation and cultural ES. The major classification systems of ES do not differ much, but only the CICES has adopted systematic hierarchic structure and has been under continuous development.

However, there are also a tradition within NR classifications, which has given attention to nontangible resources and values of nature. This has provided possibilities to make comparisons between ES and NR, wider than simply to state that their common field is provisioning ecosystem services (goods) which correspond to renewable biotic NR.

The two classifications considered here are examples of an early [15] and later [16] development towards the inclusion non-tangible resources of nature into the NR concept. Both were regarded as advanced classifications of their times. In the comparison with the CICES [19] several non-tangible ES were found in the Owen's (1971) classification of NR [15]. Reimers's (1990) generic classification included even quite a large number of non-tangible NR, which were considered to have their counterparts, partially at least, among many "new" ES, as defined in the CICESclassification. When considering the alternatives to integrate ES into natural resource classifications, the development potential of Reimers (1990) no doubt requires attention.

Another, but a specific NR field needs to be recognized as a forerunner in the identification and classification of what is now named as ES. The protective and other beneficial functions or uses of forests, including landscape and recreation values, have been discovered and adopted early in forest science and research. Many regulating and cultural ES have also long time been recognized in the forest management principles and included into forest legislations. This has probably influenced in the national NR classifications in forested countries (including perhaps the two cases considered here) but little reflected in the other general NR classifications.

The concept of environmental resources (ER) emerged about the same times as ecosystem services. Besides including material natural resources, it can be merited from the conceptual inclusion of a wide scope of non-tangible recreational and other cultural resources as well as some "environmental services" similar to regulating ES. To some extent, NR and ER are overlapping concepts. However, the ER were not brought into systematic classification.

Compared to NR, the scope of environment in concept of ER seems to be broader in regard to urban and industrial landscapes [45]. As the title suggest, the concept is closely related to environmental degradation, pollution and the development of environmental sciences.

Perhaps for the sake of clarity one may use also the longer version of natural and environmental resources (or other way round) to give the message about the wide coverage of resources meant to be taken into account. This needs more elaboration than has been possible here. 
Ecosystem services (ES) is the concept mainly developed within ecology and ecological economics. Also it is based on the concerns of the degradation of ecosystems and biotic natural resources, and in particular on the loss of biodiversity. The concept is backed by international biodiversity policies. Biodiversity is an important characteristics of nature and ES literature often regard it as the fundamental source of ES. ES is also interpreted as an anthropogenic turn of international biodiversity policies. It is also seen as the bridging concept, connecting a variety of realms and challenges (ecological, economic, political, multi-disciplinary, management, communication). The fact that ES is an anthropocentric concept is also well reflected in the wide coverage of cultural ecosystems services.

Systematic such as natural capital and environmental services at the conceptual levels already include the combination of NR and ES categories. Eurostat's "working definition" of natural resources already forms an outline for such a structure.

Natural resources, ecosystem services and environmental resources are partially overlapping concepts. Perhaps surprisingly, it seems that presently ES is the concept, which has the most precise coordinates in terms of the definition and the classifications. NR has its core contents in material resources, but this only provides a narrow scope to the resources of nature in our times. Without the advanced definitions and classifications of NR such as the two classifications examined here, NR as concept will restrict its potential in the areas such as recreation and tourism, landscape and watershed management or even in the larger frame of integrated resource management in general.

It would be useful to have a better consensus on the contents of in particular between NR and ER. The ambiguity is much do the fact that 'nature' and 'environment' are closely related and overlapping concepts. Sometimes in the literature almost the same composition of nature's components is regarded as NR in one and as ER in other context. Overlapping needs not to be entirely avoided but it is better to be coordinated so that it facilitates clear communication. Nevertheless, some overlapping is a smaller problem than the state of affairs that something essential is left out from the human knowledge about nature, ecosystems and environment urgently needed to solve challenges such as considered next.

\section{An epilogue}

"To-day, the interchange of matter and energy has grown to such immense proportions that the productive activities of people have become a potent factor of global influence on nature comparable to the action of geological or cosmic forces" [57].

Similar statements have been presented, during and after the Stockholm Conference on Human Environment in 1972, in the report of the World Commission on Environment and Development in 1987 [49] or in the contexts of two last World Environmental Conferences in Rio de Janeiro in 1992 and 2012. During the past decades these statements have received further evidence, most recently related to the planetary boundaries.

According to Rockström et al [57] anthropogenic pressures on the Earth System have reached a scale where abrupt global environmental change can no longer be excluded. A new approach to global sustainability has been proposed in which planetary boundaries are defined so that within their limits it is expected that humanity can operate safely [57, 58].

Among nine planetary boundaries defined [58] two core boundaries - climate change and biosphere integrity - have been identified as having the potential on its own to drive the Earth system into a new destabilized state should they be substantially and persistently transgressed. Therefore, there is need to address multiple environmental processes simultaneously. For example, stabilizing the climate system requires sustainable forest management and stable ocean ecosystems [58]. 
Natural resources, environmental resources and ecosystem services are related, partially overlapping but most importantly complementary concepts. While each having a bit different scientific background and application fields, neither of them alone is sufficient to guide the ways for the sustainable management, restoration and protection of the biological and physical entities of the world.

"We must not lose sight of the forest from the trees, even while we catalogue the DNA of each species". This was the answer to the question "Why study Earth System Sciences?" [59]. Planetary boundaries are one of the forests of the 21 st century.

But, there are other forests not less complex: social and political: social and political. In 1972 Gerasimov et al [56] stated "an effective and rational solution of the problems involved in preserving and improving the environment is inseparably bound up with all other social problems". They concluded: "Peaceful coexistence of all nations, permanent exchange of scientific and technological experience, implementation of coordinated international measures are indispensable for the preservation and purposive transformation of the natural environment in the interest of all mankind".

Within planetary boundaries this was formulated in a shorter way: "The prospect of tighter resource constraints and rising environmental hazards is unavoidably turning the focus onto global social equity and the planetary stewardship of Earth's life support system" [58].

The last in the list of the natural resources by N.F. Reimers in 1990 [16] was "time resources". It included an explanation: "Sharpening ecological problems are giving less and less time".

Besides time, peace, trust and co-operation seem to be among the scarcest resources in our contemporary world. These sources are not hidden in the depths of the earth and oceans, nor attainable from other planets. These only can be found from human minds, reasoning and cultures, when honestly sought, cultivated and protected. The development and employment of peaceful coexistence, trust and cooperation are the only sustainable means to establish ecologically and socially safe zones towards planetary boundaries - and remove the political, economic and cultural boundaries, which nowadays are preventing to make all this true.

\section{References}

1. Aristotle. 1972. Politics, Aristotle in Twenty-Three Volumes. Vol. XXI. London: Loeb

2. Tahvonen. O. 2000. Economic Sustainability and Scarcity of Natural Resources: A Brief Historical Review. Resources for the Future. http://www.rff.org/files/sharepoint/WorkImages/Download/RFF-IB-00-tahvonen.pdf

3. Smith, A. The Wealth of the Nations

4. Ernst, W.G. (Ed.) 2000. Earth Sciences. Processes and Issues. Cambridge University Press. $566 \mathrm{pp}$.

5. Samuelson, P.A. \& Nordhaus, W.D. 1989. Economics. McGraw-Hill. *Smith, A The Wealth of the Nations

6. Zimmerman. E.W. 1933 World Resources and Industries. New York

7. Zimmerman, E.W. 1951. World Resources and Industries. Revised edition. New York.

8. Ciriacy-Wantrup, S. V. 1938. Multiple optimum use of wild land under different economic conditions. Journal of Forestry 36(7): 665-674

9. Diller, O.O. 1950. Our forest resources. In: Smith, H-G. 1950. Conservation.of Natural Resources. John Wiley \& Sons. Pp. 1993-208.

10. Bakker, K. 2012. The "Matter of Nature" in Economic Geography. In: Trevor, J.B., Peck, J. \& Sheppard, E. The Wiley-Blackwell Companion to Economic Geography. Pp 104-117. Wiley-Blackwell. 646 pp. 
11. Robertson, M., 2012. Renaturing the Economy In: Trevor, J.B., Peck, J. \& Sheppard, E. The Wiley-Blackwell Companion to Economic Geography. Pp 372-384. Wiley-Blackwell. 646 $\mathrm{pp}$.

12. Millenium Ecosystem Assessment. 2005. Ecosystems and Human Well-Being: General Synthesis. Island Press, Washington DC.

13. Kumar, P. (Ed.) 2010. The Economics of Ecosystems and Biodiversity. Ecological and Economic Foundations. Earthscan. 410 p. (TEEB: The Economics of Ecosystems and Biodiversity).

14. Eurostat (http://ec.europa.eu/eurostat/web/environmental-data-centre-on-naturalresources/overview/natural-resource-concepts Visited September 2015)

15. Owen, O. S. 1971. Natural Resource Conservation. An Ecological Approach. New York.

16. Reimers, N.F. 1990. Prirodopolzovanie: Slovar-spravotsnik. Moskva, Miysl. 637 pp. [Natural resources management: Reference book. Moscow]

17. Stepanovskyh, A. S. 2003. Prikladnaya ekologya: ohrana okryzhayshej sredi. M. YounitiDana. $751 \mathrm{pp}$.

18. Kholmatyonov, B.M., Yu.V., Petrov, H.T. \& Egamberdiev, 2014 : New Approaches to Classification of Atmosphere Air as a Natural and Environmental Resource. Journal of Environmental Science 3 (3). http://environment.scientific-journal.com

19. Haynes-Young, R. and Potschin, M. 2013. Common International Classification of Ecosystem Services (CICES): Consultation on Version 4, August-December 2012.European Environment Agency. Revised January 2013. (www.cices.eu or www.nottingham.ac.uk/cem)

20. Saastamoinen, O., Matero, J., Horne, P., Kniivilä, M., Haltia, E Mannerkoski, H., Vaara, M., 2014. Classification of boreal forest ecosystem goods and services in Finland. Publications of the University of Eastern Finland, Reports and Studies in Forestry and Natural Sciences. No 11: 1-196. http://epublications.uef.fi/pub/urn_isbn_978-952-61-10424/urn_isbn_978-952-61-1042-4.pdf

21. Daily, G.C. 1997. Nature's services: societal dependence on natural ecosystems. Island Press, Washington DC

22. Costanza, R., d'Arge, R., de Groot, R., Farber, S., Grasso, M., Hannon, B., Limburg, K., Naeem, S., O’Neill, R.V., Paruedo, J., Raskin, R.G., Sutton, P. \& van den Belt, M. 1997. The value of the world's ecosystem services and natural capital. Nature 15 (387): 253-260.

23. UK NEA 2011. UK National Ecosystem Assessment. Technical Report. UNEP-WCMC, Cambridge. Available at: http://uknea.

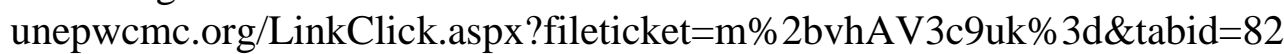

24. Kettunen, M., Vihervaara, P., Kinnunen, S., D’Amato, D., Badura, T., Argimon, M. and ten Brink, P. 2012. Socio Economic importance of ecosystem services in the Nordic Countries. Synthesis in the context of The Economics of Ecosystems and Biodiversity (TEEB). Nordic Council of Ministers. Copenhagen. Available at: http://www.ymparisto.fi/download.asp?contentid=141472

25. Jäppinen, J.-P., Heliölä, J. 2015. (Eds.) Towards a sustainable and genuinely green economy. The value and social significance of ecosystem services in Finland (TEEB for Finland). Synthesis and roadmap. The Finnish Environment 1en/2015. 144p. The Finnish Ministry of Environment, Helsinki.

26. Maes, J., Teller, A., Erhard, M., Liquete, C., Braat, L., Berry, P., Egoh, B., Puydarrieux, P., Fiorina, C., Santos, F., Paracchini, M.L., Keune, H., Wittmer, H., Hauck, J., Fiala, I., Verburg, P.H., Condé, S., Schägner, J.P., San Miguel, J., Estreguil, C., Ostermann, O., Barredo, J.I., Pereira, H.M., Stott, A., Laporte, V., Meiner, A., Olah, B., Royo Gelabert, E., 
Spyropoulou, R., Petersen, J.E., Maguire, C., Zal, N., Achilleos, E., Rubin, A., Ledoux, L., Brown, C., Raes, C., Jacobs, S., Vandewalle, M., Connor, D., Bidoglio, G., 2013. Mapping and Assessment of Ecosystems and their Services. An analytical framework for ecosystem assessments under action 5 of the EU biodiversity strategy to 2020. European Union, Luxembourg. 57 p.

27. Haines-Young, R., Potschin, M., 2012. CICES Version 4: Response to Consultation. Centre for Environmental Management, University of Nottingham. $17 \mathrm{p}$.

28. Turkelboom, F., Raquez, P., Dufrêne, M., Raes, L., Simoens, I, Jacobs, S.,Stevens, M., De Vreese, R., Panis, J. A.E., Hermy, M., Thoonen, M., Liekens, I., Fontaine, C., Dendoncker, N., van der Biest, K., Casaer, J., Heyrman, H., Meiresonne, L., Keune, H., 2013. CICES Going Local: Ecosystem Services Classification Adapted for a Highly Populated Country. In: Jacobs, S., Dendoncker, N., Keune, H. (Eds.), Ecosystem Services - Global Issues, Local Practices. pp. 223-247.

29. Alahuhta, J., Joensuu, I., Matero, J., Vuori, K-M. \& Saastamoinen, O. 2013. Freshwater ecosystem services in Finland. Reports of the Finnish Environment Institute 16/2013. 35 p. Available at: http://hdl.handle.net/10138/39076.

30. Saastamoinen, O., Matero, J., Horne, P., Kniivilä, M., Haltia, E., Mannerkoski, H., Vaara, M., 2014b. Classification of boreal forest ecosystem goods and services in Finland. Publications of the University of Eastern Finland, Reports and Studies in Forestry and Natural Sciences. No 11. 202 p.

31. Ministry of Agriculture and Forestry. 2011. Ehdotus soiden ja turvemaiden kestävän ja vastuullisen käytön ja suojelun kansalliseksi strategiaksi. Soiden ja turvemaiden kansallista strategiaa valmistelleen työryhmän ehdotus 16.2.2011. Työryhmämuistio. Ministry of Agriculture and forestry. 2011:1.

32. Suomen ympäristökeskus, Pellervon taloustutkimus, Metsätalouden kehittämiskeskus Tapio, Institute for European Environmental Policy, Helsingin yliopisto \& Pohjois-Karjalan ELYkeskus. 2013. Soiden ja turvemaiden ekosysteemipalvelujen arviointi ja arvottaminen (SuoEko-hanke) - Loppuraportti. 31 p.

33. Mace, G.M. \& Bateman, I. (Coordinating Lead Authors). 2011. Chapter 2: Conceptual Framework and Methodology. In: The UK National Ecosystem Assessment Technical Report. UNEP-WCMC, Cambridge. Available at: http://uknea.unepwcmc.org/LinkClick.aspx?fileticket $=\mathrm{m} \% 2 \mathrm{bvhAV3c9uk \% 3d \& tabid=82}$

34. Bonn', A. M S. Reed ' C. D. Evans ${ }^{\underline{h}}$ H. Joosten, Clifton Bain, Jenny Farmer, I. Emmer ${ }^{1}$, J Couwenberg, AMoxey, R. Artz, F. Tanneberger, M. von Unger ${ }^{2}$ M-A Smyth, D. Birnie. 2014. Investing in nature: Developing ecosystem service markets for peatland restoration. Ecosystem Services Volume 9, September 2014, Pages 54-65

35. Saastamoinen, O., Matero, J., Haltia, E., Horne, P., Kellomäki, S., Kniivilä, M. \& Arovuori, K. 2013. Concepts and considerations for the synthesis of ecosystem goods and services in Finland. Publications of the University of Eastern Finland. Reports and Studies in Forestry and Natural Sciences. No 10. 1-108. http://epublications.uef.fi/pub/urn_isbn_978-952-611042-4/urn_isbn_978-952-61-1042-4.pdf

36. Haynes-Young, R. and Potschin, M. (2013): Common International Classification of Ecosystem Services (CICES): Consultation on Version 4, August-December 2012.European Environment Agency. Available at: www.cices.eu or www.nottingham.ac.uk/cem

37. Carlowitz, H.C. 1713. "Sylvicultura oeconomica". Huuri, O., Huuri, L. \& Oja, S. 1989. Selostus vuonna 1713 julkaistusta Hannss Carl von Carlowitzin teoksesta Sylvicultura Oeconomica An account of Sylvicultura Oeconomica by Hannss Carl von Carlowitz, published in 1713 / Olavi Huuri, Leena Huuri, Seppo Oja. Helsinki. Metsäntutkimuslaitos. 
38. Melehov, I,S. 1981. Lomonosov i istoki nayki i lesnovo obrazovanya v Rossii. Lesnoy Zhurnal 1981 (15): 128-132. Cited in: Sankt -Peterburgskaya Gosydartsvennya Lesotechnytcheskya Akademya - Stranitsi istorii 1803-2003. Sankt-Peterburg. 2003.

39. Prophet, E. 1950. Recreational resources. In: Smith, H-G. 1950. Conservation of Natural Resources. John Wiley \& Sons. Pp. $440-465$.

40. Krott, M. 2005 Forest Policy Analysis. Springer. European Forest Institute. 323 p.

41. Forest Code of the Russian Federation 2006. Adopted by the State Duma of the Russian Federation. November 2006. Unofficial translation from Russian by the World Bank. http://faolex.fao.org/docs/texts/rus68489E.doc .

42. Petrov, A., Filioushkina, G., Kulikova, E. \& Teplyakov, V. 2004. Gosydarstvennoje upravlenije lesnim hozjaistvom. [State management of forestry). VNIILM, Moscow. 264 p.

43. McDermott, C.L., Cashore, B. \& Kanowski, P. 2010. Global Environmental

Forest Policies. An International Comparison. Earhthscan. 372 p.

44. Mather, Chapman 1995. Environmental Resources

45. Boersma, J.J \& Reijnders, L. (Eds) 2010. Principles of Environmental Sciences. Springer.

46. Hanley, N., Shogren, J. \& White, B. 2013. Introduction to Environmental Economics. Second edition. Oxford University Press. 200 p.

47. Naskali, A.2015. Kohti ekosysteemitaloutta. Tutkimus ekologisen taloustieteen perusteista ja mahdollisuuksista. Publications of the University of Eastern Finland, Dissertations in Social Sciences and Business Studies, no 94:1- 396.

48. Arovuori, K. Saastamoinen O. 2013. Classification of agricultural ecosystem goods and services in Finland. PTT Working Papers 155. 23 p.

49. de Groot, T., Fisher, b., Christie, M., Aronson, J., Braat, L., Gowdy, J., Haynes-Young, R., Maltby, E., Neuville, A., Polasky, S., Portela, R.\& Ring, I. 2010. Integrating the Ecological and Economic Dimensions in Biodiversity and Ecosystem Service Valuation. In: Kumar, P. (ed.) The Economics of Ecosystems and Biodiversity. Ecological and Economic Foundations. Pp. 9-37.

50. Report of the World Commission on Environment and Development: Our Common Future [The Brundlandt report] 1987. http://www.un-documents.net/our-common-future.pdf

51. Food and Agricultural Organisation of the United Nations. 1995. Planning for sustainable use of land resources - Towards a new approach. FAO Land and Water Bulletin 2. (http://www.fao.org/docrep/v8047e/v8047e00.htm)

52. European Commission, Food and Agriculture Organization, International Monetary Fund, Organisation for Economic Co-operation and Development, United Nations, World Bank. 2012. System of Environmental-Economic Accounting Central Framework. (http://unstats.un.org/unsd/envaccounting/White_cover.pdf).

53. United Nations. 2014. Experimental Ecosystem Accounting. New York.

54. European Commission. 2011. A resource-efficient Europe - Flagship initiative under the Europe 2020 Strategy. Communication from the Commission to the European parliament, the Council, the European economic and social committee and the Committee of the regions. COM (2011) 21

55. European Communities, International Monetary Fund, Organisation for Economic Cooperation and Development, United Nations and World Bank. 2009. System of National Accounts 2008. New York

56. Gerasimov, I.P., Mints, A.A. Preobrazhensky, V.S.Abramov, L.S., Kunitsyn, L.F., Leontyev, N.F. Mashibits, Y.G. 1972. Conclusion: The Natural Environment as Public Wealth and an Object of Scientific Research. In: Gerasimov, I.P., Mints, A.A. Preobrazhensky, V.S.Abramov, L.S., Kunitsyn, L.F., Leontyev, N.F. Mashibits, Y.G. 1972. Man, Society and 
the Environment. Geographical Aspects of the Uses of Natural Resources and Nature Conservation. Progress Publishers. Pp. 327-340 .

57. Rockström, J., W. Steffen, K. Noone, Å. Persson, F. S. Chapin, III, E. Lambin, T. M. Lenton, M. Scheffer, C. Folke, H. Schellnhuber, B. Nykvist, C. A. De Wit, T. Hughes, S. van der Leeuw, H. Rodhe, S. Sörlin, P. K. Snyder, R. Costanza, U. Svedin, M. Falkenmark, L. Karlberg, R. W. Corell, V. J. Fabry, J. Hansen, B. Walker, D. Liverman, K. Richardson, P. Crutzen, and J. Foley. 2009. Planetary boundaries:exploring the safe operating space for humanity. Ecology and Society 14 (2): 32. [online] URL: http://www.ecologyandsociety.org/vol14/iss2/art32/

58. Steffen, W., Richardson, K. Rockström, J., Cornell, S.E., Fetzer, I. , Bennett, E.M., Biggs, R. Stephen R. Carpenter, S.R., de Vries, W., de Wit, C. A., Folke, C., Gerten, D., Heinke, J., Mace, G. M., Persson, L. M., Ramanathan, V., Reyers, B. R \& Sörlin, S. 2015. Planetary boundaries: Guiding human development on a changing planet. Science 12 June 2015: 1217. [DOI:10.1126/science.aab0031]

59. Schneider, S.H. 1999. Why study Earth System Sciences. pp. 5-12. In Ernst, W.G. (Ed.). Earth Systems. Processes and Issues. Cambridge University Press. 566. pp.

60. Lele, S, Springate-Baginski O, Lakerveld R, Deb D, Dash P. 2013. Ecosystem Services: Origins, Contributions, Pitfalls, and Alternatives. Conservation and Society (11) 343-358.

61.UK National Ecosystem Assessment 2011. The UK National Ecosystem Assessment: Synthesis of the Key Findings. UNEP-WCMC, Cambridge

62. Gerasimov, I.P., Mints, A.A. Preobrazhensky, V.S.Abramov, L.S., Kunitsyn, L.F., Leontyev, N.F. Mashibits, Y.G. 1972. Man, Society and the Environment. Geographical Aspects of the Uses of Natural Resources and Nature Conservation. Progress Publishers. 340 p.

63. Dieterich, V. 1953. Forst-wirtschaftspolitik - Eine Einfuhrung. Verlag Paul Parey Hamburg und Berlin. 398 p.

64. Riegert, C., Bader, A. \& Costanza, R. 2010. German cultural history of forestry and forest functions since the early 19th century". In: Encyclopedia of Earth. http://www.eoearth.org/article/German_cultural_history_of_forestry_and_forest_functions_ since_the_early_19th_century

65. Moiseyev, N.A. 1980. Vosproidstvo lesnyh resursov. Lesnya promyshlennost. 262 pp.

66. European Commission. 2005. Thematic strategy on the sustainable use of natural resources. Communication from the Commission to the Council, the European Parliament, the European Economic and Social Committee and the Committee of the Regions. \{SEC(2005) $1683\}$ \{SEC(2005) 1684\}

67. United Nations, European Commission, International Monetary Fund, Organisation for Economic Co-operation and Development, World Bank, 2005, Handbook of National Accounting: Integrated Environmental and Economic Accounting 2003, Studies in Methods, Series F, No.61, Rev.1, Glossary, United Nations, New York, para. 7.42, EA.1

68. Petrov V.N., Zubko A.A. 2005. Ekonomytseskaya otshenka lesnoi rekreatsya. SBG. Nayka. $195 \mathrm{p}$

69. Laptev, I. 1977. The Planet of Reason (A Sociological Study of Man-Nature Relationship). Progress Publishers. Moscow.

70. Gjoksi, N. \& Sedlacko, M. 2011. Resource policies in the context of sustainable development: Current trends and challenges ahead. ESDN Quarterly Report March 2011.

71. The OECD Glossary of Statistical Terms. Available at: https://stats.oecd.org/glossary/ 